\title{
Export-led growth in the UAE: multivariate causality between primary exports, manufactured exports and economic growth
}

\author{
Athanasia S. Kalaitzi ${ }^{1} \cdot$ Emmanuel Cleeve $^{1}$
}

Received: 2 November 2016/Revised: 2 August 2017/Accepted: 10 August 2017 /

Published online: 18 September 2017

(C) The Author(s) 2017, corrected publication 11/2017. This article is an open access publication

\begin{abstract}
The principal question that this research addresses is the validity of the Export-Led Growth hypothesis (ELG) in the United Arab Emirates (UAE) over the period 1981-2012, focusing on the causality between primary exports, manufactured exports and economic growth. Unit root tests are applied to examine the timeseries properties of the variables, while the Johansen cointegration test is performed to confirm or not the existence of a long-run relationship between the variables. Moreover, the multivariate Granger causality test and a modified version of Wald test are applied to examine the direction of the short-run and long-run causality respectively. The cointegration analysis reveals that manufactured exports contribute more to economic growth than primary exports in the long-run. In addition, this research provides evidence to support a bi-directional causality between manufactured exports and economic growth in the short-run, while the Growth-Led Exports (GLE) hypothesis is valid in the long-run for UAE.
\end{abstract}

Keywords Export-led Growth · Diversification · Economic growth · Causality · UAE

JEL Classification O47 · F43 · C22

Athanasia S. Kalaitzi

kalaitzi.athanasia@gmail.com; a.kalaitzi@mmu.ac.uk

Emmanuel Cleeve

e.cleeve@mmu.ac.uk

1 Department of Accounting, Finance and Economics, Manchester Metropolitan Business School, All Saints Campus, Oxford Road, Manchester M15 6BH, UK 


\section{Introduction}

The contribution of exports to economic growth has received growing attention as economists try to account for the different levels of economic growth between countries. The growth in exports increases the inflows of foreign exchange, allowing the expansion of imports of services and capital goods, which are essential to improving productivity and economic growth (McKinnon 1964; Chenery and Strout 1966; Gylfason 1999).

Empirical evidence has shown that not all exports contribute equally to economic growth. Countries with high share of manufactured exports in total exports have achieved significant economic growth, as "manufactured exports might offer greater potential for knowledge spillovers and other externalities than primary exports" (Herzer et al. 2006, p. 325). In addition, as Blecker (2016, p. 276) notes, "Manufacturing industries have generally been the main locus of technological innovation, which is a key factor in driving long-run increases in productivity and incomes". However, Export-Led Growth hypothesis is not valid for all countries that have expanded their manufacturing sector (Blecker and Razmi 2010).

Export-Led Growth (ELG) is the strategy favored by governments, as they try to boost economic growth, but what category of exports contributes more to economic growth? Within the context of UAE economy, evidence on the causal relationship between exports and economic growth has been limited and mixed, while no study has yet examined the causality between disaggregated exports and economic growth. In particular, two studies, that by Al-Yousif (1997) and that by El-Sakka and Al-Mutairi (2000) have investigated the causality between total exports and economic growth in the UAE and their results are contradictive. Al-Yousif (1997) confirms the validity of the ELG based on a regression equation, where aggregate output is the dependent variable and export variable is the explanatory variable. This study examines the statistical significance of the coefficient of the export variable to draw conclusions for the validity of the ELG, but the causality does not necessarily run from exports to economic growth. In contrast, the study by El-Sakka and AlMutairi (2000) supports the Growth-Led Exports (GLE), using more advanced econometric techniques; however, the use of bivariate framework may lead to misleading and biased results. For this reason, the present paper uses advanced econometric techniques in a multivariate framework, overcoming the limitations of previous studies and unveiling the different causal effects that subcategories of exports can have.

The UAE is the second largest economy in the Arab World after Saudi Arabia, with a GDP of approximately US $\$ 402$ billions in 2014. During the last three decades, UAE has achieved strong economic growth and significant export diversification, being the most diversified economy in the GCC region. In particular, the share of primary exports in total merchandise exports has decreased from $84.9 \%$ in 1981 to $33.9 \%$ in 2014, while the share of manufactured exports has increased from $3.4 \%$ in 1981 to $34.6 \%$ in 2014 , indicating that there is a significant diversification process in the UAE. Furthermore, export diversification is also reflected by the share of manufactured exports in GDP, which has increased from 
around $1.6 \%$ in 1981 to approximately $32.3 \%$ in 2014 . Accordingly, this research attempts to investigate whether further increase in the degree of export diversification could accelerate economic growth in UAE, helping in designing future policies for accelerating economic growth in other resource-abundant countries.

Empirical findings provide evidence to support a short-run bi-directional causality between manufactured exports and economic growth, while the GrowthLed Exports (GLE) hypothesis is valid in the long-run for UAE. In addition, this research suggests that primary exports do not cause economic growth in the UAE in both short-run and long-run. However, primary exports are essential for the expansion of manufactured exports.

The remaining sections of this paper are organized as follows; Sect. 2 reviews the literature on the relationship between exports and economic growth, while the chosen methodology, empirical models and data sources are described in Sect. 3. Section 4, reports and interprets the empirical results, while Sect. 5 presents the summary, conclusion and policy implications of this research.

\section{Literature review}

The role of exports as an engine of economic growth is a constant subject of debate in the economic growth literature. The classical school of economics argues that trade stimulates the economic growth through exports of surplus (Smith 1776) and the utilization of comparative advantage (Ricardo 1817). According to these theories, countries can benefit from trade by specializing in the production of those goods, for which their resources are best suited and gaining materials, which they could not produce. It is interesting to note that these theories do not take into account negative factors for economic growth, such as differences in price behavior between countries and the decreasing demand for primary products, which could lead to deterioration in country's terms of trade.

According to other theories, trade often strengthens in the first instance the developed countries, whose exports consist of manufacturing products, while the under-developed countries are in danger of deterioration in terms of trade. As noted in Chaunduri (1989, p. 39), Ricardo argues that trade can increase output if the country imports 'the commodity that used the fixed input (land) in production and exports non land-using manufactures, but not otherwise'. Berrill (1960) indicates that international trade and export expansion could be an obstacle for the growth of small developing countries. In particular, as Chaudhuri (1989) notes, if trade between low and high income countries lead to the former specializing in the production of labor-intensive goods, trade can be an obstacle for further growth.

The relationship between exports and economic growth has been analyzed by several studies. Most of these studies indicate that export expansion permits the exploitation of economies of scale and increases the rate of employment in laborsurplus economies. Moreover, the export expansion leads to the adoption of advanced technologies, covering the increasing domestic and foreign demand (Balassa 1978; Feder 1982; Al-Yousif 1997; Abou-Stait 2005). In addition, some 
studies demonstrate that this positive impact appears to be particularly strong among the more developed countries and in some cases could be negligible among the least developed countries (Michaely 1977; Kavoussi 1984; Vohra 2001). As Kindleberger (1962, p. 204) notes, for a positive effect from exports to economic growth, 'there must be capital formation, technical change and reallocation of recourses'.

Moreover, several empirical studies investigate the causality between exports and economic growth. Most of these studies conclude that a unidirectional causality runs from exports to economic growth, confirming the validity of the ELG hypothesis (Yanikkaya 2003; Shirazi and Manap 2004; Abou-Stait 2005; Siliverstovs and Herzer 2006; Gbaiye et al. 2013). Other studies argue that causality runs from growth to exports or conclude that there is a bidirectional causal relationship between exports and economic growth (Panas and Vamvoukas 2002; Awokuse 2007; Narayan et al. 2007; Elbeydi et al. 2010; Mishra 2011). In the case of GLE, growth creates new needs, which cannot initially be covered by the local production, increasing the country's imports for capital equipment and improving the existing technology (Kindleberger 1962). This can cause an expansion of exports, especially of manufactures, creating virtuous circles of cumulative causation (Boggio and Barbieri 2017; Kaldor 1970). It is noticeable that several studies indicate no causal link between exports and economic growth (Jung and Marshall 1985; El-Sakka and Al-Mutairi 2000; Tang 2006). Thus, there is no consensus on whether exports cause economic growth.

A number of previous studies argue that aggregate measures may mask the different causal effects of subcategories of exports on economic growth (Ghatak et al. 1997; Tuan and Ng 1998; Abu-Qarn and Abu-Bader 2004). For example, Ghatak et al. (1997) support the ELG hypothesis for aggregate exports in Malaysia, however, non-fuel primary exports are found to have negative causal effect on economic growth. The study by Tuan and Ng (1998) indicate that there is no longrun relationship between total exports and economic growth in Hong Kong. In contrast, when total exports are decomposed into domestic exports and re-exports, a long-run relationship exists between the variables. In addition, although the study by Abu-Qarn and Abu-Bader (2004) provides little support for ELG hypothesis for total exports in Middle East and North Africa countries, manufactured exports are found to cause economic growth. Therefore, the validity or not of the ELG hypothesis depends on the measure of exports.

Moreover, previous studies investigate the impact of export composition on economic growth, indicating that not all exports contribute equally to economic growth (Fosu 1990; Herzer et al. 2006; Siliverstovs and Herzer 2006; Hosseini and Tang 2014). The reliance of economies on exports of primary products can slow down economic growth, while the expansion of manufactured exports can have a positive and significant effect on economic growth. In particular, Fosu (1990) indicates that primary exports have negligible impact on economic growth among the less developed countries (LDCs), while the manufacturing export sector has a positive and significant effect on economic growth. In addition, Siliverstovs and Herzer (2006) find that a unidirectional Granger causality exists from manufactured exports to economic growth, while primary exports do not cause economic growth in Chile. The more recent study of Hosseini and Tang (2014) indicate that non-oil 
exports have a positive effect on economic growth of Iran, while oil and gas exports have negative effect on economic growth. According to Herzer et al. (2006, p. 325), "manufactured exports might offer greater potential for knowledge spillovers and other externalities than primary exports". In general, as Sachs and Warner (1995) notes, a higher share of primary exports is associated with lower growth.

As far as the studies on UAE are concerned, the empirical literature is limited. The empirical study by Al-Yousif (1997) examines the existence of a long-run relationship between exports and economic growth in four of the Arab Gulf countries, namely Saudi Arabia, Kuwait, UAE and Oman, over the period 1973-1993. This study uses an augmented production function with exports, government expenditure and terms of trade as additional inputs of production and the two-step cointegration technique proposed by Engle and Granger (1987). The results indicate that there is no long-run relationship between exports and economic growth in all the countries under investigation. In addition, this study uses the framework proposed by Feder (1982) in order to examine the impact of exports on economic growth in the short-run. The regression results show that the short-run impact of exports on economic growth is statistically significant and positive for the selected Arab countries.

The more recent study by El-Sakka and Al-Mutairi (2000) examines the relationship between exports and growth in Arab countries, using annual time-series data and different versions of Granger's causality test. This study is based on a bivariate framework and the results show that there is no long-run relationship between exports and economic growth for all the countries under consideration. In the short run, no causal relationship between exports and economic growth exists in the case of Kuwait, Qatar, Libya, Tunis and Sudan, while there is a bidirectional causal relationship between exports and growth in the case of Oman, Algeria, Egypt, Jordan, Bahrain and Mauritania. It is noticeable that in the case of UAE (1972-1996) a unidirectional causality runs from growth to exports, while a unidirectional causality runs from exports to growth in Saudi Arabia, Iraq, Morocco and Syria. Therefore, the results show that exports in most of the Arab countries do not cause economic growth. According to El-Sakka and Al-Mutairi (2000, p. 164), "this may be partially explained by the fact that abundance of oil revenues in 9 of the 16 countries has, directly or indirectly, negatively affected the development of the export sector in the Arab region". Thus, there is no consensus on whether exports cause economic growth in the Arab World. Table 7 in Appendix summarizes some of the relevant literature.

The majority of the previous studies are based on cross sectional data and this "may result in the loss of important parametric differences between countries" (AlYousif 1997, p. 693). Furthermore, as Shirazi and Manap (2004) note, these studies are based on the assumption that "a common economic structure and similar production technology" exists across different countries, which is not realistic (Shirazi and Manap 2004, p. 474). For this reason, this study investigates the relationship between exports and economic growth for the case of UAE, using time series data. However, due to unavailability of quarterly data for the variables under consideration, annual data is used. 
Most of the earlier studies mentioned above have found a positive correlation between exports and GDP. In particular, an increase in exports raises the level of GDP and for this reason a positive correlation between exports and GDP is inevitable (Ahmad 2001). In addition, the use of the correlation coefficient as evidence of export-led growth is not adequate, as the correlation coefficient does not show the direction of the causality.

In addition, many empirical studies investigate the validity of the ELG hypothesis based on a single equation, where output is the dependent variable and export variable is the explanatory variable. These studies examine the statistical significance of the coefficient of the export variable to draw conclusions, but causality does not necessarily runs from exports to economic growth. As El-Sakka and Al-Mutairi (2000, p. 155) note, "if a bidirectional causality between these two variables exists, the estimation and tests used in the impact studies are inconsistent". The majority of the more recent studies are based on bivariate or trivariate Vector Autoregression (VAR) models and this might led to misleading and biased results, as causality tests are sensitive to omitted variables. Furthermore, most of these studies investigate the existence of a long-run causality in an Error Correction Model (ECM) context. Nevertheless, in the case of multivariate ECMs, it is not possible to indicate which explanatory variable causes the dependent variable in the long-run.

Accordingly, this paper uses a production function augmented with disaggregated exports and imports of goods and services, as causality tests are sensitive to omitted variables. Also, this study investigates the existence of a long-run causality by applying a modified version of Wald test in an augmented VAR model, developed by Toda and Yamamoto (1995), overcoming the limitations of previous studies based on ECMs.

\section{Data and methodology}

\subsection{Data}

This paper uses annual time series for UAE over the period 1981-2012, as dictated by data availability. In particular GDP (Y) is derived from the World Development Indicators Data Base, while manufactured exports and primary exports are derived from the World Trade Organization-Time Series on International Trade. The data for Gross Fixed Capital Formation and for Imports of goods and services comes from several sources. In order to employ a consistent series for these two variables, the time series for the periods 1981-1998 and 2001-2009 are taken from the IMF and are evaluated by comparing them with the available data obtained from the World Bank and the UAE National Bureau of Statistics. The missing data for the years 1999-2000 are obtained from the National Bureau of Statistics of UAE, while the data for the more recent period 2010-2012 are taken from the World Bank. In addition, the population (L) is taken from the UAE National Bureau of Statistics. All the macroeconomic variables are expressed in real terms, using the GDP deflator taken from the World Development Indicators, while the variables are expressed in 
Table 1 Descriptive statistics, 1981-2012. Source: Authors' calculations

\begin{tabular}{lllllll}
\hline Statistics & LY & LK & LL & LPX & LIMP & LMX \\
\hline Mean & 25.734 & 24.020 & 14.831 & 24.433 & 24.792 & 23.070 \\
Median & 25.716 & 23.896 & 14.743 & 24.315 & 24.735 & 23.190 \\
Maximum & 26.355 & 24.883 & 16.035 & 25.316 & 26.061 & 24.641 \\
Minimum & 25.144 & 23.293 & 13.885 & 23.591 & 23.745 & 21.250 \\
Std Dev & 0.401 & 0.523 & 0.653 & 0.501 & 0.777 & 1.037 \\
Jarque-Bera & 2.610 & 2.629 & 2.160 & 1.718 & 2.236 & 1.770 \\
(Probability) & 0.271 & 0.269 & 0.340 & 0.423 & 0.327 & 0.413 \\
Observations & 32 & 32 & 32 & 32 & 32 & 32 \\
\hline
\end{tabular}

logarithmic form. The descriptive statistics and plots of the log-transformed data are shown in Table 1 and Fig. 1 respectively.

\subsection{Methodology}

This study tests the ELG hypothesis assuming that the aggregate production of the economy can be expressed as a function of physical capital, human capital, primary exports, manufactured exports and imports, following Siliverstovs and Herzer (2006).

$$
\mathrm{Y}_{\mathrm{t}}=\mathrm{A}_{\mathrm{t}} \mathrm{K}_{\mathrm{t}}^{\alpha} \mathrm{L}_{\mathrm{t}}^{\beta}, 0<\alpha+\beta<1,
$$

where $Y_{t}$ denotes the aggregate production of the economy at time $t, A_{t}$ is the total factor productivity, while $\mathrm{K}_{\mathrm{t}}$ and $\mathrm{L}_{\mathrm{t}}$ represent the physical capital stock and human capital respectively. The constants $\alpha$ and $\beta$ are between zero and one, measuring the share of physical and human capital on income. In addition, it is assumed that the total factor productivity can be expressed as a function of primary exports, $\mathrm{PX}_{\mathrm{t}}$, manufactured exports, $\mathrm{MX}_{\mathrm{t}}$ and imports of goods and services, $\mathrm{IMP}_{\mathrm{t}}$ and other exogenous factors $\mathrm{C}_{\mathrm{t}}$ :

$$
A_{t}=f\left(P X_{t}, M_{t}, I M P_{t}, C_{t}\right)=\operatorname{PX}_{t}^{\gamma} M_{t}^{\delta} \operatorname{IMP}_{t}^{\zeta} C_{t} .
$$

Combing the Eqs. (1) and (2) the following equation is obtained:

$$
\mathrm{Y}_{\mathrm{t}}=\mathrm{C}_{\mathrm{t}} \mathrm{K}_{\mathrm{t}}^{\alpha} \mathrm{L}_{\mathrm{t}}^{\beta} \mathrm{PX}_{\mathrm{t}}^{\gamma} \mathrm{MX}_{\mathrm{t}}^{\delta} \mathrm{IMP}_{\mathrm{t}}^{\zeta}
$$

where $\alpha, \beta, \gamma, \delta$ and $\zeta$ represent the elasticities of production with respect to the inputs of production: $\mathrm{K}_{\mathrm{t}}, \mathrm{L}_{\mathrm{t}}, \mathrm{PX}_{\mathrm{t}}, \mathrm{MX}_{\mathrm{t}}$ and $\mathrm{IMP}_{\mathrm{t}}$. After taking the natural logs of both sides of equation (3), the following equation is obtained:

$$
\mathrm{LY}_{\mathrm{t}}=\mathrm{c}+\alpha \mathrm{LK}_{\mathrm{t}}+\beta \mathrm{LL}_{\mathrm{t}}+\gamma \mathrm{LPX}_{\mathrm{t}}+\delta \mathrm{LMX}_{\mathrm{t}}+\zeta \mathrm{IMP}_{\mathrm{t}}+\varepsilon_{\mathrm{t}},
$$

where $\mathrm{c}$ is the intercept, the coefficients $\alpha, \beta, \gamma, \delta$ and $\zeta$ are constant elasticities, while $\varepsilon_{\mathrm{t}}$ is the error term. 

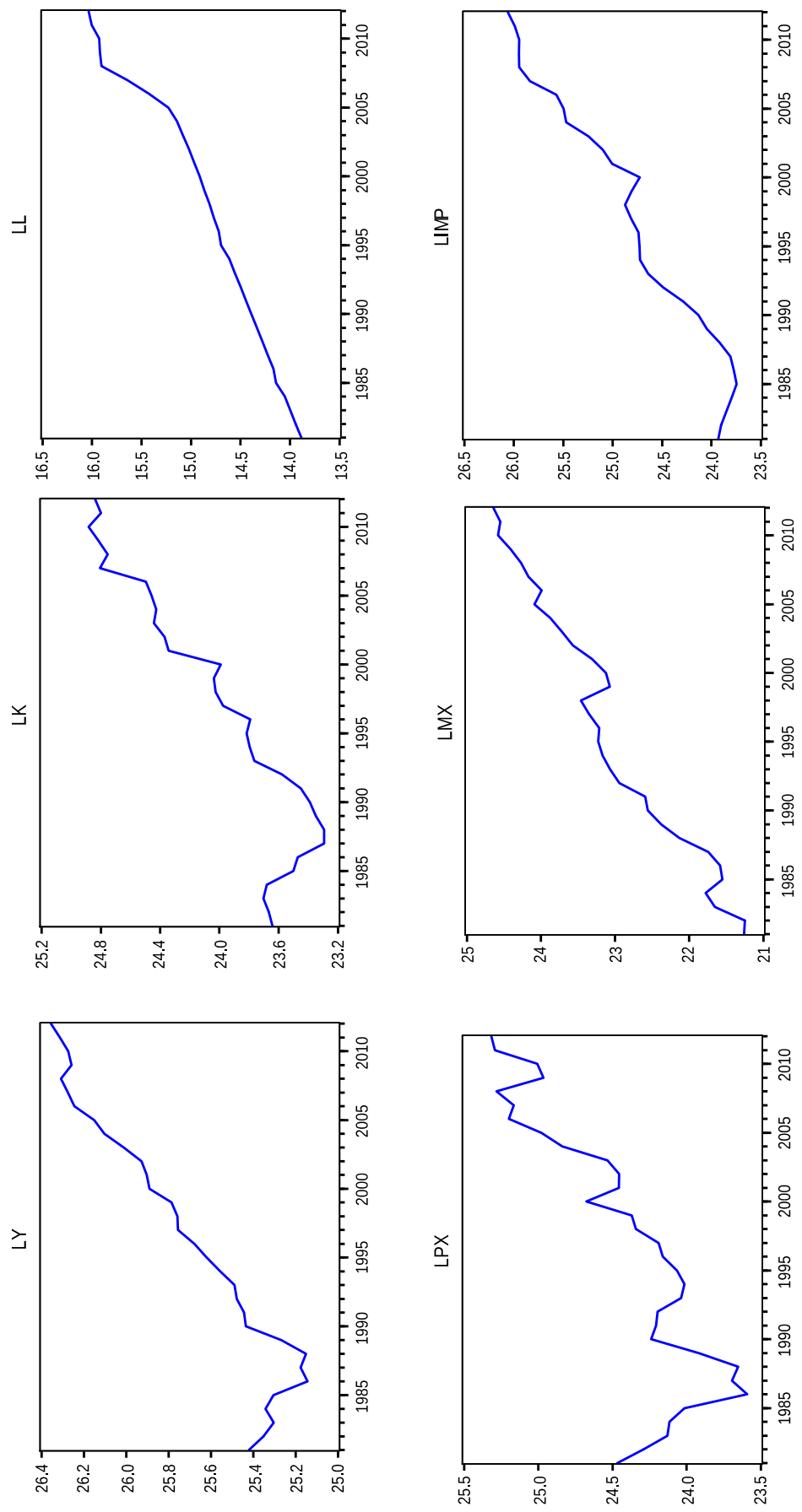
Fig. 1 Plots of the time series, 1981-2012. Source: Gross Domestic Product is taken from the WDIWorld Bank, Gross Fixed Capital formation and Imports are taken from IFS- IMF (years 1999-2000 are taken from UAE National Bureau of Statistics and years 2010-2012 are taken from World Bank). Primary and Manufactured exports are obtained from WTO- Time Series on International Trade and population is obtained from UAE National Bureau of Statistics. The graphs are produced by using the econometric software Eviews 8

In order to examine whether a causal relationship exists between primary exports, manufactured exports and economic growth in the UAE, the following tests are applied: (a) Unit root tests in order to examine the stationarity of the variables included in the model, (b) Cointegration test to confirm or not the Export-led Growth hypothesis and (c) the multivariate Granger causality test and the modified Wald test (MWALD) to investigate the direction of the short-run and long-run causality respectively.

\subsection{Unit root test}

Initially, the Augmented Dickey-Fuller (ADF) test is conducted in order to test for the presence of a unit root (Enders 1995). The ADF test is based on the following three equations:

$$
\begin{gathered}
\Delta \mathrm{Y}_{\mathrm{t}}=\gamma \mathrm{Y}_{\mathrm{t}-1}+\sum_{i=1}^{p} \beta i \Delta \mathrm{Y}_{\mathrm{t}-\mathrm{i}}+\varepsilon_{t} \\
\Delta \mathrm{Y}_{t}=\alpha_{0}+\gamma \mathrm{Y}_{\mathrm{t}-1}+\sum_{i=1}^{p} \beta i \Delta \mathrm{Y}_{\mathrm{t}-\mathrm{i}}+\varepsilon_{t} \\
\Delta \mathrm{Y}_{t}=\alpha_{0}+\gamma \mathrm{Y}_{\mathrm{t}-1}+\alpha_{2} \mathrm{t}+\sum_{i=1}^{p} \beta i \Delta \mathrm{Y}_{\mathrm{t}-\mathrm{i}}+\varepsilon_{t},
\end{gathered}
$$

where $\alpha_{0}$ and $\alpha_{2}$ represents the deterministic elements.

Equation (5) is a random walk, Eq. (6) is a random walk with intercept only, while the last equation is a random walk with intercept and time trend (Gujarati 2003). In addition the random errors are assumed to be uncorrelated and identically distributed with zero mean and variance $\sigma^{2}\left\{\varepsilon_{\mathrm{t}} \sim\right.$ ii $\left(0, \sigma^{2}\right)$ for $\left.\mathrm{t}=1,2, \cdots\right\}$. In each case, the null hypothesis is that $\gamma=0 ; \mathrm{H}_{\mathrm{o}}$ the time series is not stationary, while the alternative hypothesis is that $\gamma<0 ; \mathrm{H}_{\mathrm{a}}$ the time series is stationary.

In addition, this research applies the Phillips and Perron (1988) test (PP), which is a generalization of the Dickey-Fuller procedure that allows for serial correlation and heteroskedasticity in the error terms (Enders 1995). This test involves the following equations:

$$
\begin{gathered}
\mathrm{Y}_{\mathrm{t}}=\gamma_{0}^{*}+\gamma^{*}{ }_{1} \mathrm{y}_{\mathrm{t}-1}+\mu_{\mathrm{t}} \\
\mathrm{Y}_{t}=\gamma^{*}{ }_{0}+\gamma^{*}{ }_{1} \mathrm{y}_{\mathrm{t}-1}+\gamma^{*}{ }_{2}(\mathrm{t}-\mathrm{T} / 2)+\mu_{\mathrm{t}},
\end{gathered}
$$

where $\gamma^{*}{ }_{0}$ and $\gamma^{*}{ }_{1}$ are the deterministic elements, $T$ is the number of observations, while $\mu_{\mathrm{t}}$ is the error term. In particular, the Phillips-Perron t-statistics are modifications of the ADF t-statistics that take into account the less restrictive nature of the error process (Enders 1995). The PP test is performed by following the method suggested by Doldado et al. (1990) regarding the inclusion of constant and trend. 
According to Verbeek (2012, p. 294) "Not all series for which we cannot reject the unit root hypothesis are necessarily integrated of order one". For this reason this research also applies the test proposed by Kwiatkowski et al. (1992), where the null hypothesis is a stationary process. The Kwiatkowski-Phillips-Schmidt-Shin (KPSS) statistic is based on the residuals from the Ordinary Least Squares (OLS) regression of $y_{t}$ on the exogenous variables $x_{t}$ (constant and time trend):

$$
Y_{t}=\delta x_{t}^{\prime}+u_{t}
$$

The KPSS statistic is defined as: KPSS $=\sum_{t} S(t)^{2} /\left(T^{2} f_{0}\right)$

Where $f_{0}$ is an estimator of the residual spectrum at frequency zero and $S(t)$ is a cumulative residual function: $S(t)=\sum_{r=1}^{t} \hat{u}_{r}$, based on the residuals $\hat{\mathrm{u}}_{\mathrm{t}}$ from the equation $\mathrm{Y}_{\mathrm{t}}=\delta \mathrm{x}_{\mathrm{t}}^{\prime}+\mathrm{u}_{\mathrm{t}}$.

However, when applying the ADF, PP and KPSS tests, a structural break can be identified as evidence of non-stationarity, even if the series is stationary within each of the periods before and after the break. Since UAE economy has been subject to oil shocks during the period 1981-2012, the Saikkonen and Lütkepohl (2002) unit root test (SL) with a structural break is conducted in order to assess the stationarity of the variables. The SL test involves the following models:

$$
\begin{gathered}
\mathrm{Y}_{\mathrm{t}}=\mu_{\mathrm{o}}+\mu_{1} \mathrm{t}+\delta \mathrm{d}_{1 \mathrm{t}}+u_{\mathrm{t}} \\
\mathrm{Y}_{\mathrm{t}}=\mu_{\mathrm{o}}+\delta \mathrm{d}_{1 \mathrm{t}}+u_{\mathrm{t}},
\end{gathered}
$$

where $\mu_{0}$ is the constant term, $\mu_{1}$ and $\delta$ are the coefficients of the trend term and the shift dummy variable respectively, while $u_{t}$ is the error term. In particular, $d_{1 t}$ is a shift dummy variable with break date $\mathrm{T}_{\text {break }}: \mathrm{d}_{1 \mathrm{t}}=0$, for $\mathrm{t}<\mathrm{T}_{\text {break }}$ and $\mathrm{d}_{1 \mathrm{t}}=1$, for $\mathrm{t}>\mathrm{T}_{\text {break }}$.

\subsection{Cointegration test}

After testing for stationarity of the variables, the Johansen cointegration test (Johansen 1988, 1995) is performed in order to confirm the existence of a long-run relationship between the variables. The Johansen cointegration test is considered to have better properties than the other cointegration tests, such as the two-step EngleGranger Cointegration technique (Engle and Granger 1987). As Gonzalo (1994) notes, Johansen's cointegration test satisfies the three elements in a cointegration system, "first the existence of unit roots, second the multivariate aspect, and third the dynamics. Not taking these elements into account may create problem is estimation" (Gonzalo 1994, p. 223). Johansen's methodology estimates cointegrating vectors using a maximum likelihood procedure, taking its starting point in the VAR of order $\mathrm{p}$ given by:

$$
\mathrm{X}_{\mathrm{t}}=\mu+\sum_{i=1}^{p} \mathrm{~A}_{\mathrm{i}} \mathrm{X}_{\mathrm{t}-\mathrm{i}}+\varepsilon_{t},
$$


where $X_{t}$ is a (nx1) vector of variables that are $\mathrm{I}(1), \mu$ is a (nx1) vector of constants, $\mathrm{A}_{\mathrm{i}}$ is an $(\mathrm{n} \times \mathrm{n})$ matrix of parameters, while $\varepsilon_{t}$ is a (nx1) vector of random errors. Subtracting $X_{t-1}$ from each side of this equation and letting I be an (nxn) identity matrix, this VAR can be re-written as:

$$
\begin{gathered}
\Delta X_{t}=\mu+\Pi X_{t-1}+\sum_{i=1}^{p-1} \Gamma_{i} \Delta X_{t-i}+\varepsilon_{t} \\
\text { where } \Gamma_{i}=-\sum_{j=i+1}^{p} A_{j}, \quad \Pi=\sum_{i=1}^{p} A_{i}-I .
\end{gathered}
$$

$\Delta$ is the difference operator, $\Gamma_{\mathrm{i}}$ and $\Pi$ are the coefficient matrices, while the rank of matrix $\Pi$ provides information about the number of cointegrating vectors. In the case where the coefficient matrix $\Pi$ has rank $r<\mathrm{n}$, but not equal to zero, this means that there is cointegration and $r$ is the number of cointegrating vectors. It is important to note that in a VAR model with $n$ variables, there can be at most $r=n-1$ cointegrating relationships. In this case, $\Pi$ can be expressed as $\Pi=\alpha \beta$, where $\alpha$ and $\beta$ are n x r matrices. The elements of the matrix $\alpha$ are known as the adjustment matrix parameters in the vector error correction model and the matrix $\beta$ is the cointegrating matrix. The number of cointegrating vectors can be determined by using the likelihood ratio (LR) trace test statistic suggested by Johansen (1988). The LR trace statistic is adjusted for small sample size, as proposed by Reinsel and Ahn (1992). ${ }^{1}$

The LR trace statistic is given by the following equation:

$$
J_{\text {trace }}=-T \sum_{i=r+1}^{n} \ln (1-\lambda i)
$$

where $\mathrm{T}$ is the sample size and $\lambda$ is the eigenvalue. The trace test, tests the null hypothesis of at most $r$ cointegrating vectors against the alternative hypothesis of $n$ cointegrating vectors.

\subsection{Short-run Granger causality test}

In order to conduct the Granger causality test, a VAR model is estimated, by including the optimal lag length of each variable in each equation (Gujarati 2003). The VAR model with six endogenous variables $\left(\mathrm{LY}_{\mathrm{t}}, \mathrm{LK}_{\mathrm{t}}, \mathrm{LL}_{\mathrm{t}}, \mathrm{LPX}_{\mathrm{t}}, \mathrm{LMX}_{\mathrm{t}}\right.$, LIMP $_{\mathrm{t}}$ ) can be expressed as follows:

$$
\begin{aligned}
L Y_{t}= & \alpha_{10}+\sum_{j=1}^{p} \beta_{1 j} L Y_{t-j}+\sum_{j=1}^{p} \gamma_{1 j} L K_{t-j}+\sum_{j=1}^{p} \delta_{1 j} L L_{t-j}+\sum_{j=1}^{p} \zeta_{1 j} L P X_{t-j} \\
& +\sum_{j=1}^{p} \theta_{1 j} L M X_{t-j}+\sum_{j=1}^{p} \mu_{1 j} L I M P_{t-j}+\varepsilon_{1 t} \\
L K_{t}= & \alpha_{20}+\sum_{j=1}^{p} \beta_{2 j} L Y_{t-j}+\sum_{j=1}^{p} \gamma_{2 j} L K_{t-j}+\sum_{j=1}^{p} \delta_{2 j} L L_{t-j}+\sum_{j=1}^{p} \zeta_{2 j} L P X_{t-j} \\
& +\sum_{j=1}^{p} \theta_{2 j} L M X_{t-j}+\sum_{j=1}^{p} \mu_{2 j} L I M P_{t-j}+\varepsilon_{2 t}
\end{aligned}
$$

\footnotetext{
${ }^{1}$ Trace statistics is adjusted by using the correction factor $\left(\mathrm{T}-\mathrm{n}^{*} \mathrm{p}\right) / \mathrm{T}$ proposed by Reinsel and Ahn (1992), where $\mathrm{T}$ is the sample size, while $\mathrm{n}$ and $\mathrm{p}$ is the number of the variables and the optimal lag length respectively.
} 


$$
\begin{aligned}
L L_{t}= & \alpha_{30}+\sum_{j=1}^{p} \beta_{3 j} L Y_{t-j}+\sum_{j=1}^{p} \gamma_{3 j} L K_{t-j}+\sum_{j=1}^{p} \delta_{3 j} L L_{t-j}+\sum_{j=1}^{p} \zeta_{3 j} L P X_{t-j} \\
& +\sum_{j=1}^{p} \theta_{3 j} L M X_{t-j}+\sum_{j=1}^{p} \mu_{3 j} L I M P_{t-j}+\varepsilon_{3 t}
\end{aligned}
$$

$$
\begin{aligned}
L P X_{t}= & \alpha_{40}+\sum_{j=1}^{p} \beta_{4 j} L Y_{t-j}+\sum_{j=1}^{p} \gamma_{4 j} L K_{t-j}+\sum_{j=1}^{p} \delta_{4 j} L L_{t-j}+\sum_{j=1}^{p} \zeta_{4 j} L P X_{t-j} \\
& +\sum_{j=1}^{p} \theta_{4 j} L M X_{t-j}+\sum_{j=1}^{p} \mu_{4 j} L I M P_{t-j}+\varepsilon_{4 t}
\end{aligned}
$$

$$
\begin{aligned}
L M X_{t}= & \alpha_{50}+\sum_{j=1}^{p} \beta_{5 j} L Y_{t-j}+\sum_{j=1}^{p} \gamma_{5 j} L K_{t-j}+\sum_{j=1}^{p} \delta_{5 j} L L_{t-j}+\sum_{j=1}^{p} \zeta_{5 j} L P X_{t-j} \\
& +\sum_{j=1}^{p} \theta_{5 j} L M X_{t-j}+\sum_{j=1}^{p} \mu_{5 j} L I M P_{t-j}+\varepsilon_{5 t}
\end{aligned}
$$

$$
\begin{aligned}
\operatorname{LIMP}_{t}= & \alpha_{60}+\sum_{j=1}^{p} \beta_{6 j} L Y_{t-j}+\sum_{j=1}^{p} \gamma_{6 j} L K_{t-j}+\sum_{j=1}^{p} \delta_{6 j} L L_{t-j}+\sum_{j=1}^{p} \zeta_{6 j} L P X_{t-j} \\
& +\sum_{j=1}^{p} \theta_{6 j} L M X_{t-j}+\sum_{j=1}^{p} \mu_{6 j} L I M P_{t-j}+\varepsilon_{6 t} .
\end{aligned}
$$

$L Y t$ represents the variable of economic growth, while $\mathrm{LK}_{\mathrm{t}}, \mathrm{LL}_{\mathrm{t}}, \mathrm{LPX}_{\mathrm{t}}, \mathrm{LMX}_{\mathrm{t}}$, and LIMP $_{t}$ represent the right-hand side variables of the Eq. (4). In addition, exogenous variables can be included in the VAR model, such as structural breaks, without adding equations to the system. In the case where the variables are cointegrated, the causality can be tested by estimating the following restricted VAR model (VECM):

$$
\begin{aligned}
\Delta L Y_{t}= & \sum_{j=1}^{p} \beta_{1 j} \Delta L Y_{t-j}+\sum_{j=1}^{p} \gamma_{1 j} \Delta L K_{t-j}+\sum_{j=1}^{p} \delta_{1 j} \Delta L L_{t-j}+\sum_{j=1}^{p} \zeta_{1 j} \Delta L P X_{t-j} \\
& +\sum_{j=1}^{p} \theta_{1 j} \Delta L M X_{t-j}+\sum_{j=1}^{p} \mu_{1 j} \Delta L I M P_{t-j}-\lambda_{y} E C T_{t-1}+\varepsilon_{1 t}, \\
\Delta L K_{t}= & \sum_{j=1}^{p} \beta_{2 j} \Delta L Y_{t-j}+\sum_{j=1}^{p} \gamma_{2 j} \Delta L K_{t-j}+\sum_{j=1}^{p} \delta_{2 j} \Delta L L_{t-j}+\sum_{j=1}^{p} \zeta_{2 j} \Delta L P X_{t-j} \\
& +\sum_{j=1}^{p} \theta_{2 j} \Delta L M X_{t-j}+\sum_{j=1}^{p} \mu_{2 j} \Delta L I M P_{t-j}-\lambda_{k} E C T_{t-1}+\varepsilon_{2 t} \\
\Delta L L_{t}= & \sum_{j=1}^{p} \beta_{3 j} \Delta L Y_{t-j}+\sum_{j=1}^{p} \gamma_{3 j} \Delta L K_{t-j}+\sum_{j=1}^{p} \delta_{3 j} \Delta L L_{t-j}+\sum_{j=1}^{p} \zeta_{3 j} \Delta L P X_{t-j} \\
& +\sum_{j=1}^{p} \theta_{3 j} \Delta L M X_{t-j}+\sum_{j=1}^{p} \mu_{3 j} \Delta L I M P_{t-j}-\lambda_{L} E C T_{t-1}+\varepsilon_{3 t} \\
\Delta L P X_{t}= & \sum_{j=1}^{p} \beta_{4 j} \Delta L Y_{t-j}+\sum_{j=1}^{p} \gamma_{4 j} \Delta L K_{t-j}+\sum_{j=1}^{p} \delta_{4 j} \Delta L L_{t-j}+\sum_{j=1}^{p} \zeta_{4 j} \Delta L P X_{t-j} \\
& +\sum_{j=1}^{p} \theta_{4 j} \Delta L M X_{t-j}+\sum_{j=1}^{p} \mu_{4 j} \Delta L I M P_{t-j}-\lambda_{p x} E C T_{t-1}+\varepsilon_{4 t} \\
\Delta L M X_{t}= & \sum_{j=1}^{p} \beta_{5 j} \Delta L Y_{t-j}+\sum_{j=1}^{p} \gamma_{5 j} \Delta L K_{t-j}+\sum_{j=1}^{p} \delta_{5 j} \Delta L L_{t-j}+\sum_{j=1}^{p} \zeta_{5 j} \Delta L P X_{t-j} \\
& +\sum_{j=1}^{p} \theta_{5 j} \Delta L M X_{t-j}+\sum_{j=1}^{p} \mu_{5 j} \Delta L I M P_{t-j}-\lambda_{m x} E C T_{t-1}+\varepsilon_{5 t}
\end{aligned}
$$




$$
\begin{aligned}
\Delta L I M P_{t}= & \sum_{j=1}^{p} \beta_{6 j} \Delta L Y_{t-j}+\sum_{j=1}^{p} \gamma_{6 j} \Delta L K_{t-j}+\sum_{j=1}^{p} \delta_{6 j} \Delta L L_{t-j}+\sum_{j=1}^{p} \zeta_{6 j} \Delta L P X_{t-j} \\
& +\sum_{j=1}^{p} \theta_{6 j} \Delta L M X_{t-j}+\sum_{j=1}^{p} \mu_{6 j} \Delta L I M P_{t-j}-\lambda_{i m p} E C T_{t-1}+\varepsilon_{6 t}
\end{aligned}
$$

where $\Delta$ is the difference operator, $\beta_{\mathrm{ij}}, \gamma_{\mathrm{ij}}, \delta_{\mathrm{ij}}, \zeta_{\mathrm{ij}}, \theta_{\mathrm{ij}}, \mu_{\mathrm{ij}}$ and $\lambda_{\mathrm{ij}}$ are the regression coefficients and $\mathrm{ECT}_{\mathrm{t}}-1$ is the error correction term derived from the cointegration equation.

Once the models have been estimated, multivariate specification tests are used to assess whether the models are well specified and stable. In particular, these tests include the Jarque-Bera Normality test, the Portmanteau and Breusch-Godfrey LM test for the existence of autocorrelation, the White Heteroskedasticity test, the Multivariate ARCH test and the AR roots stability test. In addition, the cumulative sum of recursive residuals (CUSUM) and the CUSUM of squares (CUSUMQ) tests are applied in order to assess the parameter constancy of the ECM estimates. Specifically, the CUSUM test detects systematic changes, while CUSUMQ test detects haphazard changes in the parameters (Brown et al. 1975). The CUSUM test proposed by Brown et al. (1975) is based on the statistic:

$$
\mathrm{W}_{\mathrm{t}}=\sum_{k+1}^{t} w_{t} / s \quad t=k+1, \ldots T
$$

where $\mathrm{s}$ is the standard deviation of the recursive residuals $\left(\mathrm{w}_{\mathrm{t}}\right)$, which is defined as:

$$
w_{t}=\left(y_{t}-x_{t}^{\prime} b_{t-1}\right) /\left(1+x_{t}^{\prime}\left(X_{t-1}{ }^{\prime} X_{t-1}\right)^{-1} x_{t}\right)^{1 / 2},
$$

where the numerator $y_{t}-x_{t}^{\prime} b_{t-1}$ is the forecast error, $b_{t-1}$ is the estimated coefficient vector up to period $t-1$ and $x_{t}{ }_{t}$ is the row vector of observations on the regressors in period $\mathrm{t}$. The $\mathrm{X}_{\mathrm{t}-1}$ denotes the $(\mathrm{t}-1) \times k$ matrix of the regressors from period 1 to period $t-1$. If the $b$ vector changes, $W_{t}$ will tend to diverge from the zero mean value line, while if $\mathrm{b}$ vector remains constant, $\mathrm{E}\left(\mathrm{W}_{\mathrm{t}}\right)=0$. The test shows parameter instability if the cumulative sum of the recursive residuals lies outside the area between the two $5 \%$ critical lines, the distance between which increases with t.

The CUSUM of Squares test uses the square recursive residuals, $\mathrm{w}_{\mathrm{t}}^{2}$ and is based on the plot of the statistic:

$$
S_{t}=\left(\sum_{k+1}^{t} w_{t}^{2}\right) /\left(\sum_{k+1}^{T} w_{t}^{2}\right), \quad \text { where } \mathrm{t}=\mathrm{k}+1, \ldots, \mathrm{T} .
$$

The expected value of $S_{t}$, under the null hypothesis of $b_{t}$ 's constancy is $E\left(S_{t}\right)=$ $(\mathrm{t}-\mathrm{k}) /(\mathrm{T}-\mathrm{k})$, which goes from zero at $\mathrm{t}=\mathrm{k}$ to unity at $\mathrm{t}=\mathrm{T}$. In this test the $\mathrm{S}_{\mathrm{t}}$ are plotted together with the 5\% significance lines and, as in the CUSUM test, movements outside the $5 \%$ critical lines of parameter stability, indicates instability in the equation during the sample period. In the case, where CUSUM test or CUSUMQ test shows evidence of structural instability, an exogenous variable should be included in order to obtain more efficient estimates. 
After estimating the restricted or unrestricted VAR model and assessing the constancy of the estimated parameters, this research applies the multivariate causality test (Granger 1969, 1988). The causality from primary exports to economic growth can be examined by conducting the Chi square test and the null hypothesis "primary exports do not Granger cause economic growth" $\left(H_{0}: \sum_{j=1}^{p} \zeta_{1 j}=0\right)$ is tested against the alternative hypothesis "primary exports Granger cause economic growth" $\left(H_{A}: \sum_{j=1}^{p} \zeta_{1 j} \neq 0\right)$. To examine the causality from manufactured exports to economic growth, the null hypothesis "manufactured exports do not Granger cause economic growth" $\left(H_{0}: \sum_{j=1}^{p} \theta_{1 j}=0\right)$ is tested against the alternative hypothesis "manufactured exports Granger cause economic growth" $\left(H_{A}: \sum_{j=1}^{p} \theta_{1 j} \neq 0\right)$. Moreover, the null hypothesis "economic growth does not Granger cause primary exports" $\left(H_{0}: \sum_{j=1}^{p} \beta_{4 j}=0\right)$ is tested against the alternative hypothesis "economic growth Granger causes primary exports" $\left(H_{A}: \sum_{j=1}^{p} \beta_{4 j} \neq 0\right)$. Finally, the null hypothesis "economic growth does not Granger cause manufactured exports" $\left(H_{0}: \sum_{j=1}^{p} \beta_{5 j}=0\right)$ is tested against the alternative hypothesis "economic growth Granger causes manufactured exports" $\left(H_{A}: \sum_{j=1}^{p} \beta_{5 j} \neq 0\right)$.

\subsection{Long-run Granger causality test}

This paper also examines the long-run causality between disaggregated exports and economic growth in the UAE. The majority of the recent studies examine the direction of the long-run causality in an ECM context (Herzer et al. 2006; Awokuse 2007; Mishra 2011; Hosseini and Tang 2014). In these studies, the long-run causality is determined by the significance of the error correction coefficient in each equation. Nevertheless, in the case of multivariate ECMs, it is not possible to indicate which explanatory variable causes the dependent variable. For example, if the coefficient $\lambda_{y}$ of the error correction term in equation (21) is significant $\left(\lambda_{y} \neq 0\right)$, a long-run causality runs from the explanatory variables to the dependent variable, but it is not possible to indicate whether exports cause economic growth. For this reason, this paper applies the modified version of the Granger causality test (MWALD) proposed by Toda and Yamamoto (1995). In the present paper, the Toda and Yamamoto Granger causality test involves the following model:

$$
\begin{aligned}
L Y_{t}= & \alpha_{10}+\sum_{j=1}^{p+d \max } \beta_{1 j} L Y_{t-j}+\sum_{j=1}^{p+d \max } \gamma_{1 j} L K_{t-j}+\sum_{j=1}^{p+d \max } \delta_{1 j} L L_{t-j} \\
& +\sum_{j=1}^{p+d \max } \zeta_{1 j} L P X_{t-j}+\sum_{j=1}^{p+d \max } \theta_{1 j} L M X_{t-j}+\sum_{j=1}^{p+d \max } \mu_{1 j} L I M P_{t-j} \\
& +\varepsilon_{1 t} \\
L K_{t}= & \alpha_{20}+\sum_{j=1}^{p+d \max } \beta_{2 j} L Y_{t-j}+\sum_{j=1}^{p+d \max } \gamma_{2 j} L K_{t-j}+\sum_{j=1}^{p+d \max } \delta_{2 j} L L_{t-j} \\
& +\sum_{j=1}^{p+d \max } \zeta_{2 j} L P X_{t-j}+\sum_{j=1}^{p+d \max } \theta_{2 j} L M X_{t-j}+\sum_{j=1}^{p+d \max } \mu_{2 j} L I M P_{t-j} \\
& +\varepsilon_{2 t}
\end{aligned}
$$




$$
\begin{aligned}
L L_{t}= & \alpha_{30}+\sum_{j=1}^{p+d \max } \beta_{3 j} L Y_{t-j}+\sum_{j=1}^{p+d \max } \gamma_{3 j} L K_{t-j}+\sum_{j=1}^{p+d \max } \delta_{3 j} L L_{t-j} \\
& +\sum_{j=1}^{p+d \max } \zeta_{3 j} L P X_{t-j}+\sum_{j=1}^{p+d \max } \theta_{3 j} L M X_{t-j}+\sum_{j=1}^{p+d \max } \mu_{3 j} L I M P_{t-j} \\
& +\varepsilon_{3 t}
\end{aligned}
$$

$$
\begin{aligned}
L P X_{t}= & \alpha_{40}+\sum_{j=1}^{p+d \max } \beta_{4 j} L Y_{t-j}+\sum_{j=1}^{p+d \max } \gamma_{4 j} L K_{t-j}+\sum_{j=1}^{p+d \max } \delta_{4 j} L L_{t-j} \\
& +\sum_{j=1}^{p+d \max } \zeta_{4 j} L P X_{t-j}+\sum_{j=1}^{p+d \max } \theta_{4 j} L M X_{t-j}+\sum_{j=1}^{p+d \max } \mu_{4 j} L I M P_{t-j} \\
& +\varepsilon_{4 t}
\end{aligned}
$$

$$
\begin{aligned}
L M X_{t}= & \alpha_{50}+\sum_{j=1}^{p+d \max } \beta_{5 j} L Y_{t-j}+\sum_{j=1}^{p+d \max } \gamma_{5 j} L K_{t-j}+\sum_{j=1}^{p+d \max } \delta_{5 j} L L_{t-j} \\
& +\sum_{j=1}^{p+d \max } \zeta_{5 j} L P X_{t-j}+\sum_{j=1}^{p+d \max } \theta_{5 j} L M X_{t-j}+\sum_{j=1}^{p+d \max } \mu_{5 j} L I M P_{t-j} \\
& +\varepsilon_{5 t}
\end{aligned}
$$

$$
\begin{aligned}
L I M P_{t}= & \alpha_{60}+\sum_{j=1}^{p+d \max } \beta_{6 j} L Y_{t-j}+\sum_{j=1}^{p+d \max } \gamma_{6 j} L K_{t-j}+\sum_{j=1}^{p+d \max } \delta_{6 j} L L_{t-j} \\
& +\sum_{j=1}^{p+d \max } \zeta_{6 j} L P X_{t-j}+\sum_{j=1}^{p+d \max } \theta_{6 j} L M X_{t-j}+\sum_{j=1}^{p+d \max } \mu_{6 j} L I M P_{t-j} \\
& +\varepsilon_{6 t}
\end{aligned}
$$

where $\mathrm{p}$ is the optimal lag length, selected by minimizing the value of Schwartz Information Criterion (SIC), while dmax is the maximum order of integration of the variables in the model. In particular, the selected lag length (p) is augmented by the maximum order of integration (dmax) and the Chi square test is applied to the first $\mathrm{p}$ VAR coefficients.

\section{Empirical results}

\subsection{Unit root test}

Table 2 presents the results of the ADF, PP, KPSS and SL unit root tests at levels. The ADF, PP and SL results indicate that the null hypothesis of non-stationarity cannot be rejected for all the variables at 5\% significance level. In addition, the KPSS test results indicate that the null hypothesis of stationarity is rejected for all the variables at conventional levels of significance.

In contrast, after taking the first difference of LY, LK, LPX, LMX and LIMP, the null hypothesis of unit root can be rejected at $1 \%$ level of significance, while the first-differenced series of LL is found to be stationary at $5 \%$ significance level. In addition, the KPSS unit root test results indicate that the null hypothesis of stationary process cannot be rejected for all the variables at $1 \%$ significance level. Hence, all the test results indicate that the time series for the period 1981-2012 are integrated of order one I(1). 
Since all variables are $\mathrm{I}(1)$, the cointegration test is applied to investigate the existence of a long-run relationship between the variables. The results are presented in Table 3.

Table 2 ADF, PP, KPSS and SL test results at logarithmic level

\begin{tabular}{|c|c|c|c|c|c|c|c|}
\hline \multirow[b]{2}{*}{ LY } & \multirow{2}{*}{$\frac{\mathrm{ADF}}{-3.45^{*(\mathrm{a})}[0]}$} & \multirow{2}{*}{$\frac{P P}{-3.41^{(a)}\{3\}}$} & \multirow{2}{*}{$\begin{array}{l}\text { KPSS } \\
0.13^{*^{(a)}}\{4\}\end{array}$} & \multicolumn{2}{|c|}{ SL without trend } & \multicolumn{2}{|c|}{ SL with trend } \\
\hline & & & & $0.77[0]$ & 1990 & $-1.09[0]$ & 1986 \\
\hline LK & $-2.36^{(\mathrm{a})}[0]$ & $-2.36^{(a)}\{6\}$ & $0.15^{* *(a)}\{4\}$ & $0.11[0]$ & 2001 & $-1.45[0]$ & 2001 \\
\hline LL & $-2.02^{(a)}[1]$ & $5.84^{(\mathrm{c})}\{1\}$ & $0.16^{* *(a)}\{4\}$ & $0.05[1]$ & 2008 & $-2.64[1]$ & 2008 \\
\hline LPX & $-3.09^{(a)}[0]$ & $-3.09^{(\mathrm{a})}\{2\}$ & $0.17 * *$ (a) $\{3\}$ & $0.50[0]$ & 2001 & $-1.24[0]$ & 2001 \\
\hline LMX & $-2.16^{(\mathrm{a})}[0]$ & $-2.25^{(\mathrm{a})}\{2\}$ & $0.73 * * *^{(b)}\{4\}$ & $-0.18[0]$ & 1986 & $-1.83[0]$ & 1986 \\
\hline LIMP & $-2.91^{(a)}[0]$ & $-2.92^{(a)}\{2\}$ & $0.72 * *$ (b) $\{4\}$ & $-0.97[0]$ & 1988 & $-2.79 *[0]$ & 1999 \\
\hline
\end{tabular}

Numbers in [] are the optimal lags, chosen based on Schwarz Information Criterion (SIC)

Bandwidth in \{\} (Newey-West automatic) using Bartlett kernel estimation method. The maximum lag length for the ADF test is found by rounding up $\mathrm{P}_{\max }=\left[12^{*}(\mathrm{~T} / 100)^{1 / 4}\right]=\left[12^{*}(38 / 100)^{1 / 4}\right] \cong 9($ Schwert 1989). All the time series are tested for the unit root including intercept and trend (a), intercept only (b) and no constant or trend (c). The letters in brackets indicate the selected model following Doldado et al. (1990)

$*$, **, *** denote the rejection of the null hypothesis at 10,5 and $1 \%$ respectively

Table 3 ADF, PP, KPSS and SL test results at first difference

\begin{tabular}{|c|c|c|c|c|c|c|c|}
\hline & $\mathrm{ADF}$ & PP & KPSS & SL Without & & SL With & nd \\
\hline $\operatorname{DLY}^{(\mathrm{b})}$ & $-4.32^{* * *(b)}[0]$ & $-4.30^{* * *(b)}\{1\}$ & $\begin{array}{c}0.30^{(b)} \\
\{2\}\end{array}$ & $-5.14 * * *[0]$ & 1986 & $\begin{array}{c}-4.50 * * * \\
{[0]}\end{array}$ & 1990 \\
\hline $\operatorname{DLK}^{(\mathrm{c})}$ & $-4.84^{* * *(\mathrm{c})}[0]$ & $-4.88^{* * *(\mathrm{c})}\{2\}$ & $\begin{array}{c}0.29^{(b)} \\
\{1\}\end{array}$ & $-4.85 * * *[0]$ & 2001 & $\begin{array}{c}-4.95 * * * \\
{[0]}\end{array}$ & 2001 \\
\hline $\operatorname{DLL}^{(b)}$ & $-3.04^{* *(b)}[0]$ & $-3.04^{* *(b)}\{3\}$ & $\begin{array}{c}0.22^{(b)} \\
\{2\}\end{array}$ & $-3.75 * * *[1]$ & 2008 & $\begin{array}{c}-3.46^{* *} \\
{[1]}\end{array}$ & 2008 \\
\hline $\operatorname{DLPX}^{(\mathrm{c})}$ & $-4.90^{* * *(\mathrm{c})}[0]$ & $-4.89^{* * *(\mathrm{c})}\{3\}$ & $\begin{array}{c}0.28^{(b)} \\
\{2\}\end{array}$ & $-7.41 * * *[7]$ & 2001 & $\begin{array}{c}-6.92 * * * \\
{[7]}\end{array}$ & 2001 \\
\hline $\operatorname{DLMX}^{(\mathrm{b})}$ & $-5.08^{* * *(b)}[0]$ & $-5.29 * * *(\mathrm{~b})\{9\}$ & $\begin{array}{c}0.13^{(b)} \\
\{7\}\end{array}$ & $-5.58 * * *[0]$ & 1986 & $\begin{array}{c}-5.23 * * * \\
{[0]}\end{array}$ & 1986 \\
\hline $\operatorname{DLIMP}^{(\mathrm{b})}$ & $-3.81 * * *(b)[0]$ & $-3.72 * * *(\mathrm{~b})\{2\}$ & $\begin{array}{c}0.19^{(b)} \\
\{3\}\end{array}$ & $-5.39 * * *[0]$ & 1999 & $\begin{array}{c}-5.14 * * * \\
{[0]}\end{array}$ & 1999 \\
\hline
\end{tabular}

Numbers in [ ] are the optimal lags, chosen based on Schwarz Information Criterion (SIC). Bandwidth in \{ \} (Newey-West automatic) using Bartlett kernel estimation method. The maximum lag length for the ADF test is found by rounding up Pmax $=\left[12 *(T / 100)^{1 / 4}\right]=\left[12^{*}(38 / 100)^{1 / 4}\right] \cong 9$ (Schwert 1989). All the time series are tested for the unit root including intercept and trend (a), intercept only (b) and no constant or trend (c). The letters in brackets indicate the selected model following Doldado et al. (1990)

$*$, **, *** denote the rejection of the null hypothesis at 10,5 and $1 \%$ respectively 
Table 4 Johansen's Cointegration test results

\begin{tabular}{lllll}
\hline $\begin{array}{l}\text { Hypothesized number of } \\
\text { cointegrating equations }\end{array}$ & Adjusted trace statistic & \multicolumn{2}{l}{ Critical value } \\
\cline { 3 - 5 } & & $1 \%$ & $5 \%$ & $10 \%$ \\
\hline $\mathrm{r}=0$ & $119.32^{* * * *}$ & 111.01 & 102.14 & 97.18 \\
$\mathrm{r} \leq 1$ & 70.57 & 84.45 & 76.07 & 71.86 \\
$\mathrm{r} \leq 2$ & 43.74 & 60.16 & 53.12 & 49.65 \\
$\mathrm{r} \leq 3$ & 21.55 & 41.07 & 34.91 & 32.00 \\
\hline
\end{tabular}

Critical values are taken from Osterwald-Lenum (1992). The model includes a restricted constant (Model selection based on Pantula, 1989). The lag length for the cointegration test is determined by minimizing the Schwarz Information Criterion (SIC), while the diagnostic tests reveal that the residuals are multivariate normal and homoscedastic, while there is no evidence of serial correlation

$*, * *$ and $* * *$ indicate rejection at 10,5 and $1 \%$ significance level respectively

\subsection{Cointegration test}

The Johansen cointegration test is conducted in order to investigate the existence of a long-run relationship between the variables. The null hypothesis of no cointegration is rejected at $1 \%$ significance level, indicating the existence of one cointegrating vector. The results are presented in Table 4.

The cointegrating vector is estimated after normalizing on LY and the following long-run relationship is obtained. The t-ratios are reported in parentheses:

$$
\begin{aligned}
L Y_{t}= & \underset{(7.267)}{1.151^{* * *}} L K_{t}-\underset{(1.561)}{0.214} L L_{t}+\underset{(2.477)}{0.319^{* *}} L P X_{t}+\underset{(10.849)}{1.665^{* * *}} L M X_{t} \\
& -\underset{(8.037)}{2.309^{* * *}} L I M P_{t}+\underset{(8.043)}{12.184^{* * *}}
\end{aligned}
$$

From the above equation, a $1 \%$ increase in real primary exports leads to a $0.319 \%$ increase in real GDP, while a $1 \%$ increase in manufactured exports rises real GDP by $1.665 \%$. In addition, real GDP increases by $1.151 \%$ in response to a $1 \%$ increase in physical capital. In contrast, $1 \%$ increase in population and imports can lead to a decrease in real GDP by 0.214 and $2.309 \%$ respectively. Therefore, manufactured exports seem to contribute more than primary exports to economic growth, through knowledge spillover effects and other externalities.

\subsection{Vector error correction model}

Since the variables are integrated of order one and cointegrated, the Granger causality is applied in VECM $^{2}$ and the results are reported in Table 5.

\footnotetext{
2 The model is estimated with the inclusion of an impulse dummy variable (DUM00) for the year 2000, as the CUSUMQ plot of the initially estimated ECM for economic growth showed evidence of structural instability. In the second half of 2000, due to the production cuts by OPEC, the oil price increased approximately by 200\% comparing with the 1999 level, reaching over US \$30 per barrel. The estimated ECM without the inclusion of the dummy variable is not reported here, but is available upon request.
} 
Table 5 Short-run Granger causality test

\begin{tabular}{llllllll}
\hline Dependent variable & \multicolumn{7}{l}{ Source of causation } \\
\cline { 2 - 8 } & $\begin{array}{l}\Delta \mathrm{LY}_{\mathrm{t}} \\
\chi^{2}(1)\end{array}$ & $\begin{array}{l}\Delta \mathrm{LK}_{\mathrm{t}} \\
\chi^{2}(1)\end{array}$ & $\begin{array}{l}\Delta \mathrm{LL}_{\mathrm{t}} \\
\chi^{2}(1)\end{array}$ & $\begin{array}{l}\Delta \mathrm{LPX}_{\mathrm{t}} \\
\chi^{2}(1)\end{array}$ & $\begin{array}{l}\Delta \mathrm{LMX}_{\mathrm{t}} \\
\chi^{2}(1)\end{array}$ & $\begin{array}{l}\Delta \mathrm{LIMP}_{\mathrm{t}} \\
\chi^{2}(1)\end{array}$ & $\begin{array}{l}\text { ALL } \\
\chi^{2}(5)\end{array}$ \\
\hline$\Delta \mathrm{LY}_{\mathrm{t}}$ & - & 0.059 & 0.137 & 0.473 & $7.715^{* * *}$ & 0.701 & $16.640^{* * *}$ \\
$\Delta \mathrm{LK}_{\mathrm{t}}$ & 0.680 & - & 0.057 & 0.433 & 0.000 & 0.129 & $10.111^{*}$ \\
$\Delta \mathrm{LL}_{\mathrm{t}}$ & 0.007 & 1.940 & - & 0.207 & 1.335 & 0.237 & 4.877 \\
$\Delta \mathrm{LPX}_{\mathrm{t}}$ & 0.321 & 0.558 & 1.776 & - & $3.699 *$ & 0.416 & 9.051 \\
$\Delta \mathrm{LMX}_{\mathrm{t}}$ & $6.977 * * *$ & 0.960 & $5.703 * *$ & 2.100 & - & $5.284 * *$ & $16.748^{* * *}$ \\
$\Delta \mathrm{LIMP}_{\mathrm{t}}$ & 2.493 & 0.437 & 0.694 & 0.356 & 0.111 & - & $9.446^{*}$ \\
\hline
\end{tabular}

The diagnostic tests reveal that the residuals are multivariate normal and homoscedastic and there is no evidence of serial correlation. In addition, the stability of the VECM is checked by calculating the inverse roots of the characteristic AR polynomial. Df in parentheses

$* * *$ and $* * *$ present significance at $10 \%, 5 \%$ and $1 \%$ levels, respectively

The short-run Granger causality results show that the null hypothesis of noncausality from primary exports to economic growth cannot be rejected at conventional significance levels, indicating that the ELG hypothesis for primary exports is not valid in the UAE. In contrast, bidirectional causality exists between manufactured exports and economic growth at 1\% significance level over the period 1981-2012. Moreover, the results show that there is a unidirectional causality from human capital and imports to manufactured exports. Thus, given that manufactured exports cause economic growth, human capital and imports indirectly cause economic growth.

Since the aim of this research focuses on the relationship between exports and economic growth, emphasis is placed on the stability of the parameters of estimated ECMs for economic growth and disaggregated exports. The constancy of the parameters of the ECMs is assessed by applying the CUSUM and CUSUMQ (Fig. 2). As it can be seen from the CUSUM plots, there is no movement outside the $5 \%$ critical lines, suggesting parameter stability. The estimated models for economic growth and disaggregated exports, including the impulse dummy DUM00, are stable even during the oil crisis of 1986 and financial crisis of 2008. Therefore, there is no reason to test for the presence of a second structural break.

\subsection{Toda-Yamamoto Granger causality test}

The maximum order of integration for the variables is $\mathrm{d}_{\max }=1$, while the optimal lag length, based on Schwarz Information Criterion, is one. Therefore the selected lag length $(\mathrm{p}=1)$ is augmented by the maximum order of integration $\left(\mathrm{d}_{\max }=1\right)$ and the Wald tests are applied to the first $\mathrm{p}$ VAR coefficients. The results are presented in Table 6.

The results of the MWALD causality test show that there is no evidence to support the ELG hypothesis in the long-run. The null hypothesis that LPX does not Granger cause LY and the null hypothesis that LMX does not Granger cause LY cannot be rejected at any conventional significance level. In contrast, the results suggest that a direct long-run causality exists, running from economic growth to 

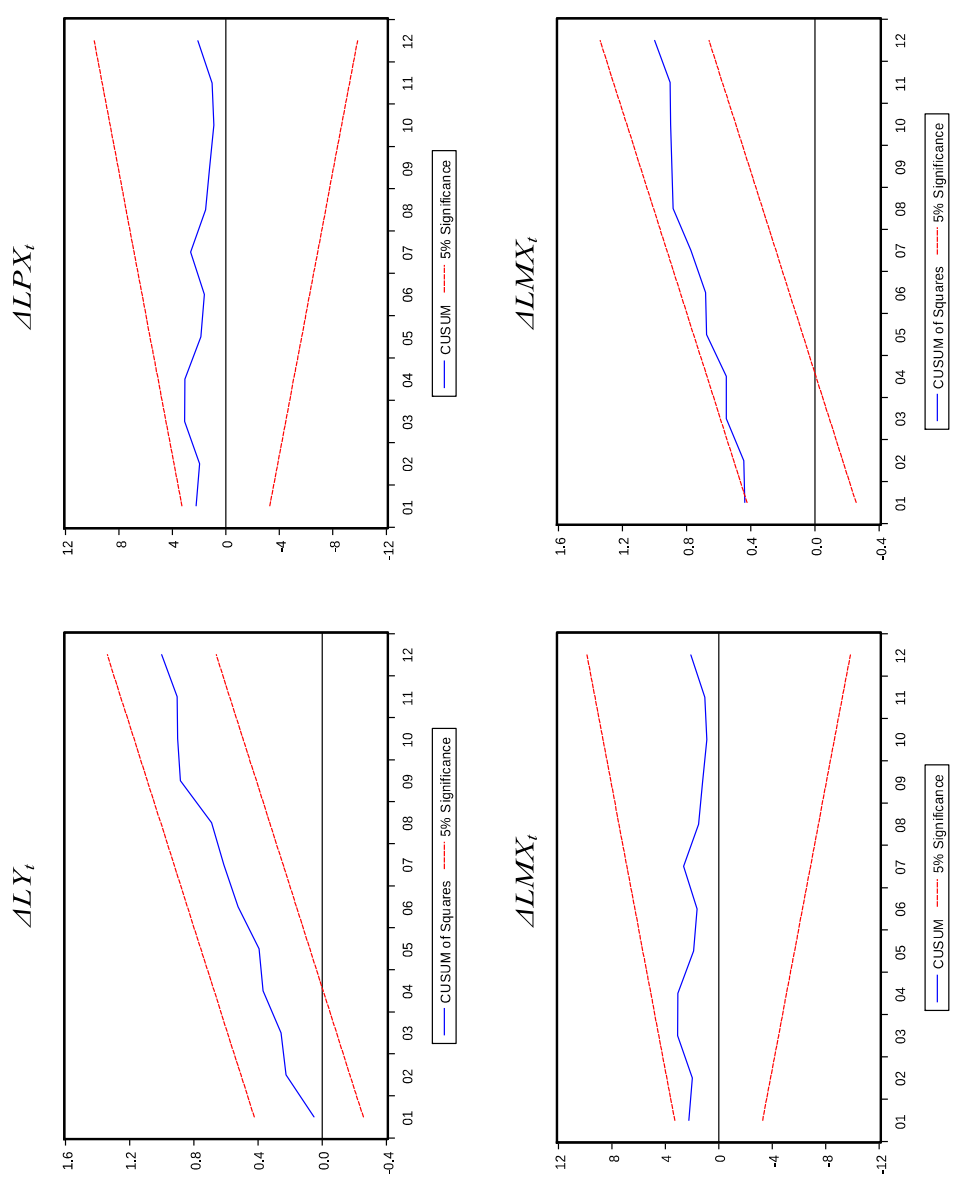

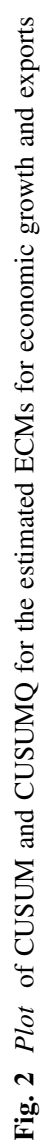
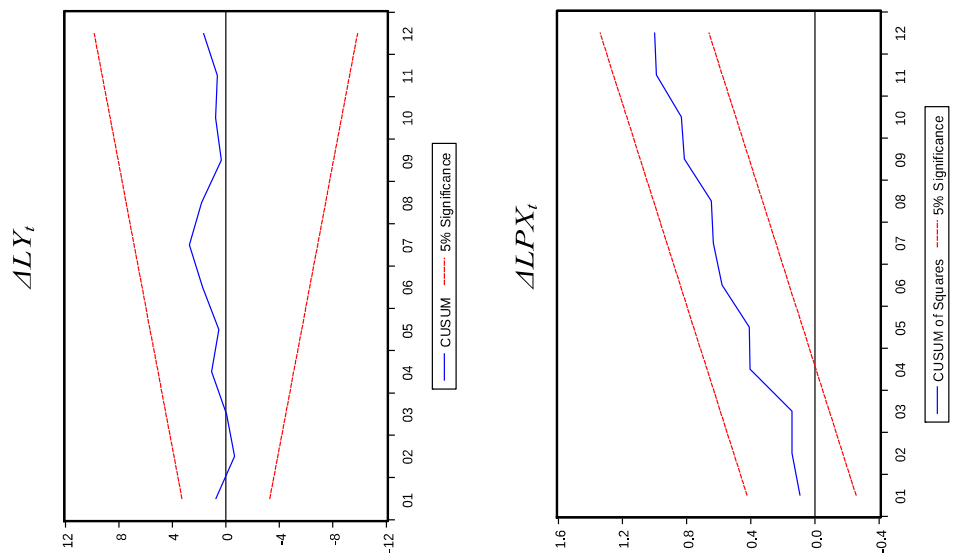
Table 6 Granger Causality based on Toda-Yamamoto procedure

\begin{tabular}{llllllll}
\hline Dependent variable & \multicolumn{6}{l}{ Source of causation } \\
\cline { 2 - 8 } & $\begin{array}{lllllll}\mathrm{LY}_{\mathrm{t}} \\
\chi^{2}(1)\end{array}$ & $\begin{array}{l}\mathrm{LK}_{\mathrm{t}} \\
\chi^{2}(1)\end{array}$ & $\begin{array}{l}\mathrm{LL}_{\mathrm{t}} \\
\chi^{2}(1)\end{array}$ & $\begin{array}{l}\mathrm{LPX}_{\mathrm{t}} \\
\chi^{2}(1)\end{array}$ & $\begin{array}{l}\mathrm{LMX}_{\mathrm{t}} \\
\chi^{2}(1)\end{array}$ & $\begin{array}{l}\mathrm{LIMP}_{\mathrm{t}} \\
\chi^{2}(1)\end{array}$ & $\begin{array}{l}\text { ALL } \\
\chi^{2}(5)\end{array}$ \\
\hline $\mathrm{LY}_{\mathrm{t}}$ & - & 0.628 & 0.388 & 0.828 & 1.729 & 0.120 & 7.824 \\
$\mathrm{LK}_{\mathrm{t}}$ & $3.554^{*}$ & - & 0.089 & 0.325 & 0.038 & 0.029 & 8.275 \\
$\mathrm{LL}_{\mathrm{t}}$ & 0.127 & 0.642 & - & 0.583 & 0.054 & 0.038 & 1.758 \\
$\mathrm{LPX}_{\mathrm{t}}$ & 0.773 & 2.614 & 0.999 & - & 0.164 & 0.241 & $9.323^{*}$ \\
$\mathrm{LMX}_{\mathrm{t}}$ & $10.327^{* * *}$ & $8.887^{* * *}$ & 1.750 & $5.692^{* *}$ & - & $20.309^{* * *}$ & $28.693^{* * *}$ \\
LIMP $_{\mathrm{t}}$ & $4.223^{* *}$ & 2.513 & 0.246 & 1.160 & 0.308 & - & $9.276^{*}$ \\
\hline
\end{tabular}

The VAR model is estimated with the inclusion of an impulse dummy variable for the year 2000. The diagnostic tests for the select VAR(p) model prior to the application of the Toda-Yamamoto procedure reveal that the residuals are multivariate normal and homoscedastic and there is no evidence of serial correlation

Df in parentheses

$*, * *$ and $* * *$ present significance at $10 \%, 5 \%$ and $1 \%$ levels, respectively

manufactured exports. In particular, the null hypothesis that LY does not Granger cause LMX can be rejected at $1 \%$ significance level, indicating that the GLE is valid for the case of UAE during 1981-2012.

This result shows that economic growth can cause an increase in manufactured exports, by increasing the national production, the capacity to import essential materials for domestic production and improving the existing technology. At the same time, a significant causality runs from primary exports to manufactured exports at 5\% level, indicating that primary exports are still essential for the expansion of manufactured exports. Moreover, manufactured exports are also affected directly by physical capital and imports of goods and services at $1 \%$ significance level, indicating that investments on advanced technology and imports in the form of inputs contribute to the expansion of manufactured exports.

\section{Conclusion}

This paper provides evidence on the causal relationship between primary exports, manufactured exports and economic growth in the UAE from 1981 to 2012. The cointegration results confirm the existence of a long-run relationship between the variables under consideration. Disaggregating merchandise exports into primary and manufactured exports, the cointegration analysis reveals that manufactured exports contribute more to economic growth than primary exports. These findings are consistent with previous studies, which argued that manufactured exports offer knowledge spillover effects and other externalities, enhancing economic growth (e.g. Fosu 1990; Abu-Qarn and Abu-Bader 2004; Herzer et al. 2006; Siliverstovs and Herzer 2006). 
The short-run causality analysis based on disaggregated exports confirms the existence of bidirectional causality between manufactured exports and economic growth, which is consistent with previous studies (e.g. Awokuse 2007; Narayan et al. 2007; Elbeydi et al. 2010). In addition the empirical results reveal that economic growth causes manufactured exports in the long-run over the period 1981-2012. This result shows that economic growth can cause an increase in manufactured exports, by increasing the national production, the capacity to import essential materials for domestic production and improving the existing technology. This result is similar with that of El-Sakka and Al-Mutairi (2000), which supports the GLE hypothesis for UAE over the period 1972-1996. However, the study by ElSakka and Al-Mutairi is based on bivariate Granger causality tests, using total exports and not disaggregated exports.

The empirical results also provide evidence that primary exports, contrary to the generally held belief, do not cause economic growth in UAE in both short-run and long-run. However, a significant causality runs from primary exports to manufactured exports in the long-run, indicating that primary exports are still essential for the expansion of UAE manufactured exports. Thus, the government of UAE should continue the successful export promotion policy, focusing on manufactured exports in order to accelerate economic growth in UAE. However, emphasis should be placed on human capital accumulation, as this factor indirectly causes economic growth through manufactured exports in the short-run.

The fact that UAE is defined by different characteristics may limit the generalizability of our findings to oil-producing countries. However, researching the causal relationship between exports and economic growth in UAE could help in designing future policies for accelerating socio-economic growth in less developed resource-abundant countries.

The case of UAE should be explored in depth in this area and the present study provides a basis to target future research in a deeper disaggregation of export components. Furthermore, the causal effect of export destination diversification on economic growth may need to be taken into consideration by future studies.

\section{Compliance with ethical standards}

Conflict of interest The authors declare that they have no conflict of interest.

Open Access This article is distributed under the terms of the Creative Commons Attribution 4.0 International License (http://creativecommons.org/licenses/by/4.0/), which permits unrestricted use, distribution, and reproduction in any medium, provided you give appropriate credit to the original author(s) and the source, provide a link to the Creative Commons license, and indicate if changes were made.

\section{Appendix}

See Table 7 in Appendix. 
Table 7 A brief framework of related literature on the causality between Exports and Economic Growth

\begin{tabular}{|c|c|c|c|c|c|}
\hline Study & Countries & Period & Method & Variables & Results \\
\hline $\begin{array}{l}\text { Michaely } \\
\text { (1977) }\end{array}$ & $42 \mathrm{LDCs}$ & $\begin{array}{l}\text { 1950-1973 } \\
\quad \text { (annual } \\
\text { data) }\end{array}$ & $\begin{array}{l}\text { Spearman's } \\
\text { rank } \\
\text { correlation }\end{array}$ & $\begin{array}{r}\text { Exports/GNP, GNP } \\
\text { per capita growth }\end{array}$ & $\begin{array}{l}\text { ELG, which is } \\
\text { particularly strong } \\
\text { among the more } \\
\text { developed } \\
\text { countries }\end{array}$ \\
\hline $\begin{array}{l}\text { Balassa } \\
\quad(1978)\end{array}$ & $\begin{array}{l}11 \text { countries } \\
\text { with } \\
\text { industrial } \\
\text { base }\end{array}$ & $\begin{array}{l}\text { 1960-1973 } \\
\quad \text { annual } \\
\text { data) }\end{array}$ & $\begin{array}{l}\text { Spearman rank } \\
\text { correlation, } \\
\text { OLS }\end{array}$ & $\begin{array}{l}\text { Total output growth, } \\
\text { total exports, } \\
\text { manufactured } \\
\text { exports, } \\
\text { manufacturing } \\
\text { output, labor } \\
\text { force, domestic } \\
\text { capital, foreign } \\
\text { capital }\end{array}$ & ELG \\
\hline $\begin{array}{l}\text { Feder } \\
\qquad(1982)\end{array}$ & $\begin{array}{l}31 \text { semi- } \\
\text { industrialized } \\
\text { LDCs }\end{array}$ & $\begin{array}{l}\text { 1964-1973 } \\
\quad \text { annual } \\
\text { data) }\end{array}$ & OLS & $\begin{array}{l}\text { GDP growth, } \\
\text { growth of exports, } \\
\text { investments/GDP, } \\
\text { population growth }\end{array}$ & ELG \\
\hline $\begin{array}{c}\text { Kavoussi } \\
\text { (1984) }\end{array}$ & $\begin{array}{l}73 \text { low and } \\
\text { middle- } \\
\text { income } \\
\text { developing } \\
\text { countries }\end{array}$ & $\begin{array}{l}\text { 1960-1978 } \\
\quad \text { annual } \\
\text { data) }\end{array}$ & $\begin{array}{l}\text { Spearman rank } \\
\text { correlation, } \\
\text { OLS }\end{array}$ & $\begin{array}{l}\text { Export growth, GNP } \\
\text { growth, share of } \\
\text { manufactured } \\
\text { goods in total } \\
\text { exports }\end{array}$ & $\begin{array}{l}\text { ELG, with } \\
\text { manufactured } \\
\text { exports having } \\
\text { more significant } \\
\text { effect on growth } \\
\text { in the more } \\
\text { advanced } \\
\text { developing } \\
\text { countries }\end{array}$ \\
\hline $\begin{array}{l}\text { Jung and } \\
\text { Marshall } \\
\text { (1985) }\end{array}$ & 37 LDCs & $\begin{array}{l}\text { 1950-1981 } \\
\quad \text { (annual } \\
\text { data) }\end{array}$ & $\begin{array}{l}\text { Granger } \\
\text { causality test }\end{array}$ & GDP and Exports & $\begin{array}{l}\text { ELG: Indonesia, } \\
\text { Egypt, Costa Rica } \\
\text { and Ecuador } \\
\text { No causality exists } \\
\text { in other LDCs }\end{array}$ \\
\hline Fosu (1990) & 64 LDCs & $\begin{array}{l}\text { 1960-1980 } \\
\quad \text { annual } \\
\text { data) }\end{array}$ & OLS & $\begin{array}{l}\text { GDP growth, capital } \\
\text { growth, labor } \\
\text { force growth, } \\
\text { growth of } \\
\text { merchandise } \\
\text { exports, } \\
\text { manufactured } \\
\text { exports/total } \\
\text { exports }\end{array}$ & $\begin{array}{l}\text { ELG, with } \\
\text { manufacturing } \\
\text { export sector } \\
\text { having a positive } \\
\text { and significant } \\
\text { effect on } \\
\text { economic growth }\end{array}$ \\
\hline $\begin{array}{c}\text { Al-Yousif } \\
\text { (1997) }\end{array}$ & $\begin{array}{l}\text { S. Arabia, } \\
\text { Kuwait, UAE } \\
\text { and Oman }\end{array}$ & $\begin{array}{l}\text { 1973-1993 } \\
\quad \text { (annual } \\
\text { data) }\end{array}$ & $\begin{array}{l}\text { Two step } \\
\text { cointegration } \\
\text { technique and } \\
\text { OLS }\end{array}$ & $\begin{array}{l}\text { GDP growth, } \\
\text { exports growth, } \\
\text { gross domestic } \\
\text { investments/GDP, } \\
\text { government } \\
\text { expenditure, terms } \\
\text { of trade }\end{array}$ & $\begin{array}{l}\text { ELG in the short- } \\
\text { run, while no } \\
\text { long-run } \\
\text { relationship exists }\end{array}$ \\
\hline
\end{tabular}


Table 7 continued

\begin{tabular}{|c|c|c|c|c|c|}
\hline Study & Countries & Period & Method & Variables & Results \\
\hline $\begin{array}{l}\text { El-Sakka } \\
\text { and Al- } \\
\text { Mutairi } \\
(2000)\end{array}$ & Arab countries & $\begin{array}{l}\text { 1970-1999 } \\
\quad \text { (annual } \\
\text { data) }\end{array}$ & $\begin{array}{l}\text { Granger } \\
\text { causality tests }\end{array}$ & $\begin{array}{l}\text { GDP and total } \\
\text { exports }\end{array}$ & $\begin{array}{l}\text { No causality: } \\
\text { Kuwait, Qatar, } \\
\text { Libya, Tunis and } \\
\text { Sudan } \\
\text { ELG-GLE: Oman, } \\
\text { Algeria, Egypt, } \\
\text { Jordan, Bahrain } \\
\text { and Mauritania } \\
\text { GLE: UAE } \\
\text { ELG: S. Arabia, } \\
\text { Iraq, Morocco } \\
\text { and Syria }\end{array}$ \\
\hline $\begin{array}{l}\text { Herzer et al. } \\
\text { (2006) }\end{array}$ & Chile & $\begin{array}{l}\text { 1960-2001 } \\
\text { (annual } \\
\text { data) }\end{array}$ & $\begin{array}{l}\text { Cointegration } \\
\text { tests, VECM, } \\
\text { Granger } \\
\text { Causality } \\
\text { test, Dynamic } \\
\text { OLS }\end{array}$ & $\begin{array}{l}\text { Imports, } \\
\text { manufactured and } \\
\text { primary exports, } \\
\text { Non-export GDP, } \\
\text { capital stock, } \\
\text { working } \\
\text { population }\end{array}$ & ELG \\
\hline $\begin{array}{l}\text { Siliverstovs } \\
\text { and } \\
\text { Herzer } \\
(2006)\end{array}$ & Chile & $\begin{array}{l}\text { 1960-2001 } \\
\text { (annual) }\end{array}$ & $\begin{array}{l}\text { VAR, Granger } \\
\text { causality test }\end{array}$ & $\begin{array}{l}\text { Manufactured and } \\
\text { primary exports, } \\
\text { Non-export GDP, } \\
\text { imports of capital } \\
\text { goods, capital } \\
\text { stock, working } \\
\text { population }\end{array}$ & $\begin{array}{l}\text { ELG (causality runs } \\
\text { only from } \\
\text { manufactured } \\
\text { exports to } \\
\text { economic growth) }\end{array}$ \\
\hline $\begin{array}{l}\text { Narayan } \\
\text { et al. } \\
(2007)\end{array}$ & $\begin{array}{l}\text { Fiji } \\
\text { Papua New } \\
\text { Guinea }\end{array}$ & $\begin{array}{c}\text { 1960-2001 } \\
\text { 1961-1999 } \\
\text { (annual } \\
\text { data) }\end{array}$ & $\begin{array}{l}\text { Bounds testing } \\
\text { procedure } \\
\text { and Granger } \\
\text { causality test }\end{array}$ & $\begin{array}{l}\text { GDP, exports and } \\
\text { imports }\end{array}$ & $\begin{array}{l}\text { ELG-GLE in short- } \\
\text { run (PNG) and } \\
\text { ELG in the long- } \\
\text { run (Fiji) }\end{array}$ \\
\hline $\begin{array}{l}\text { Mishra } \\
\quad(2011)\end{array}$ & India & $\begin{array}{l}\text { 1970-2009 } \\
\quad \begin{array}{l}\text { (annual } \\
\text { data) }\end{array}\end{array}$ & $\begin{array}{l}\text { Johansen's } \\
\text { cointegration } \\
\text { test, ECM } \\
\text { and Granger } \\
\text { causality test }\end{array}$ & $\begin{array}{l}\text { Sum of oil and non- } \\
\text { oil exports, GDP }\end{array}$ & GLE in the long-run \\
\hline $\begin{array}{l}\text { Hosseini } \\
\text { and Tang } \\
(2014)\end{array}$ & Iran & $\begin{array}{c}\text { 1970-2008 } \\
\text { (annual) }\end{array}$ & $\begin{array}{l}\text { Johansen's } \\
\text { cointegration } \\
\text { test, VECM, } \\
\text { Granger } \\
\text { causality test }\end{array}$ & $\begin{array}{l}\text { GDP, non-oil } \\
\text { exports, oil and } \\
\text { gas exports, labor } \\
\text { force, capital, } \\
\text { imports }\end{array}$ & $\begin{array}{l}\text { ELG in the short- } \\
\text { run }\end{array}$ \\
\hline
\end{tabular}

\section{References}

Abou-Stait, F. (2005). Are exports the engine of Economic Growth? An application of cointegration and causality analysis for Egypt 1997-2003. African Development Bank, Economic Research working paper series, (76) July.

Abu-Qarn, A. S., \& Abu-Bader, S. (2004). The validity of the ELG hypothesis in the MENA region: Cointegration and error correction model analysis. Applied Economics, 36(15), 1685-1695.

Ahmad, J. (2001). Causality between exports and economic growth: What do the econometric studies tell us? Pacific Economic Review, 6(1), 147-167. 
Al-Yousif, K. (1997). Exports and economic growth: Some empirical evidence from the Arab Gulf Countries. Applied Economics, 29(6), 693-697.

Awokuse, T. O. (2007). Causality between exports, imports and economic growth: Evidence from transition economies. Economic Letters, 94(3), 389-395.

Balassa, B. (1978). Exports and economic growth: Further evidence. Journal of Development Economics, 5(2), 181-189.

Berrill, K. E. (1960). International trade and the rate of economic growth. The Economic History Review, 12(3), 351-359.

Blecker, R. A. (2016). International Trade and Development. In L. P. Rochon \& S. Rossi (Eds.), An introduction to macroeconomics: a heterodox approach to economic analysis (pp. 259-282). Cheltenham: Edward Elgar Publishing.

Blecker, R. A., \& Razmi, A. (2010). Export-led growth, real exchange rates and the fallacy of composition. In M. Setterfield (Ed.), Handbook of alternative theories of economic growth (pp. 379-396). Cheltenham: Edward Elgar Publishing.

Boggio, L., \& Barbieri, L. (2017). International competitiveness in post-Keynesian growth theory: Controversies and empirical evidence. Cambridge Journal of Economics, 41(1), 25-47.

Brown, R. L., Durbin, J., \& Evans, J. M. (1975). Techniques for testing the constancy of regression relationships over time. Journal of the Royal Statistical Society, 37(2), 149-192.

Chaudhuri, P. (1989). The economic theory of growth. London: Harvester Wheatsheaf.

Chenery, H. B., \& Strout, A. M. (1966). Foreign assistance and economic development. American Economic Review, 56(4), 679-733.

Doldado, J., Jenkinson, T., \& Sosvilla-Rivero, S. (1990). Cointegration and unit roots. Journal of Economic Surveys, 4(3), 249-273.

Elbeydi, K. R. M., Hamuda, A. M., \& Gazda, V. (2010). The relationship between export and economic growth in Libya Arab Jamahiriya. Theoretical and Applied economics, 17(1), 69-76.

El-Sakka, M. I., \& Al-Mutairi, N. H. (2000). Exports and economic growth: The Arab experience. The Pakistan Development Review, 39(2), 153-169.

Enders, W. (1995). Applied econometric time series. New York: Wiley.

Engle, R. F., \& Granger, C. W. J. (1987). Cointegration and error correction: Representation, estimation and testing. Econometrica, 55(2), 251-276.

Feder, G. (1982). On exports and economic growth. Journal of Development Economics, 12(1), 59-73.

Fosu, A. K. (1990). Export composition and impact of exports on economic growth of developing countries. Economics Letters, 34(1), 67-71.

Gbaiye, O. G., Ogundipe, A., Osabuohien, E., Olugbire, O., Adeniran, O. A., Bolaji-Olutunji, K. A., et al. (2013). Agricultural Exports and Economic Growth in Nigeria (1980-2010). Journal of Economics and Sustainable Development, 4(16), 1-5.

Ghatak, S., Milner, C., \& Utkulu, U. (1997). Exports, export composition and growth: Cointegration and causality evidence for Malaysia. Applied Economics, 29(2), 213-223.

Gonzalo, J. (1994). Five alternative methods for estimating long run relationships. Journal of Econometrics, 60(1), 203-233.

Granger, C. W. J. (1969). Investigating causal relations by economic models and cross-spectral models. Econometrica, 37(3), 424-438.

Granger, C. W. J. (1988). Some recent development in a concept of causality. Journal of Econometrics, 39(1), 199-211.

Gujarati, D. N. (2003). Basic econometrics (4th ed.). Boston: McGraw-Hill.

Gylfason, T. (1999). Exports, inflation and growth. World Development, 27(6), 1031-1057.

Herzer, D., Nowak-Lehmann, F. D., \& Siliverstovs, B. (2006). Export-led growth in chile: sssessing the role of export composition in productivity growth. The Developing Economies, 44(3), 306-328.

Hosseini, S. M. P., \& Tang, C. F. (2014). The effects of oil and non-oil exports on economic growth: A case study of the Iranian economy. Economic Research-Ekonomska Istraživanja, 27(1), 427-441.

Johansen, S. (1988). Statistical analysis of cointegrating vectors. Journal of Economic Dynamics and Control, 12(2), 231-254.

Johansen, S. (1995). Likelihood-based inference in cointegrated vector autoregressive models. Oxford: Oxford University Press.

Jung, W. S., \& Marshall, P. J. (1985). Exports, growth and causality in developing countries. Journal of Development Economics, 18(1), 1-12.

Kaldor, N. (1970). The case for regional policies. Scottish Journal of Political Economy, 18, 337-347. 
Kavoussi, R. M. (1984). Export expansion and economic growth: Further empirical evidence. Journal of Development Economics, 14(1), 241-250.

Kindleberger, C. P. (1962). Foreign trade and the national economy. New Haven and London: Yale University Press.

Kwiatkowski, D., Phillips, P. C. B., Schmidt, P., \& Shin, Y. (1992). Testing the null hypothesis of stationarity against the alternative of a unit root: How sure are we that economic time series have a unit root? Journal of Econometrics, 54(1-3), 159-178.

McKinnon, R. I. (1964). Foreign exchange constraints in economic development and efficient aid allocation. The Economic Journal, 74(294), 388-409.

Michaely, M. (1977). Exports and growth, an empirical investigation. Journal of Development Economics, 4(1), 49-53.

Mishra, P. K. (2011). Exports and economic growth: Indian scene. SCMS Journal of Indian Management, $8(2), 17-26$.

Narayan, P. K., Narayan, S., Prasad, B. C., \& Prasad, A. (2007). Export-led growth hypothesis: Evidence from Papua New Guinea and Fiji. Journal of Economic Studies, 34(4), 341-351.

Osterwald-Lenum, M. (1992). A note with quantiles of the asymptotic distribution of the maximum likelihood cointegration rank test Statistics. Oxford Bulletin of Economics and Statistics, 54(3), 461-472.

Panas, E., \& Vamvoukas, G. (2002). Further evidence on the Export-Led Growth hypothesis. Applied Economics Letters, 9(11), 731-735.

Pantula, S. G. (1989). Testing for unit roots in time series data. Econometric Theory, 5(2), 256-271.

Phillips, P. C. B., \& Perron, P. (1988). Testing for a unit root in time series regression. Biometrica, 75(2), 335-346.

Reinsel, G. C., \& Ahn, S. K. (1992). Vector autoregressive models with unit roots and reduced rank structure: Estimation, likelihood ratio tests and forecasting. Journal of Time Series Analysis, 13(4), 353-375.

Ricardo, D. (1817). Principles of political economy and taxation. London: John Murray.

Sachs, J. D. and Warner, A. M. (1995). Natural resource abundance and economic growth. National Bureau of Economic Research working paper, (5398), Cambridge, MA.

Saikkonen, P., \& Lütkepohl, H. (2002). Testing for a unit root in a time series with a level shift at unknown time. Econometric Theory, 18(2), 313-348.

Schwert, G. W. (1989). Test for unit roots: A Monte Carlo investigation. Journal of Business and Economic Statistics, 7(2), 147-159.

Shirazi, N. S., \& Manap, T. A. A. (2004). Exports and economic growth Nexus: The case of Pakistan. The Pakistan Development Review, 43(4), 563-581.

Siliverstovs, B., \& Herzer, D. (2006). Export-led growth hypothesis: Evidence for Chile. Applied Economics Letters, 13(5), 319-324.

Smith, A. (1776, reprinted 1821). An inquiry into the Nature and Causes of the wealth of Nations. $5^{\text {th }}$ ed., London: Methuen and Co., Ltd

Tang, T. C. (2006). New evidence on export expansion, economic growth and causality in China. Applied Economics Letters, 13(12), 801-803.

Toda, H. Y., \& Yamamoto, T. (1995). Statistical inferences in vector autoregressions with possibly integrated processes. Journal of Econometrics, 66(1-2), 225-250.

Tuan, C., \& Ng, L. F. Y. (1998). Export trade, trade derivatives, and economic growth of Hong Kong: A new scenario. Journal of International Trade and Economic Development, 7(1), 111-137.

Verbeek, M. J. C. M. (2012). A guide to modern econometrics (4th ed.). Chichester: John Wiley and Sons.

Vohra, R. (2001). Export and economic growth: Further time series evidence from less developed countries. International Advances in Economic Research, 7(3), 345-350.

Yanikkaya, H. (2003). Trade openness and economic growth: A cross-country empirical investigation. Journal of Development Economics, 72(1), 57-89. 